Approved for public release; distributton is unlimited.

Fuels Inventories in the

Los Alamos National Laboratory Region: 1997

\section{Los Alamos \\ NATIONAL LABORATORY}

Los Alamos National Laboratory is operated by the University of California for the United States Department of Energy under contract W-7405-ENG-36. 
Edited by Hector Hinojosa, Group CIC-1

An Affirmative Action/Equal Opportunity Employer

This report was prepared as an account of work sponsored by an agency of the United States Government. Neither The Regents of the University of Califormia, the United States

Government nor any agency thereof, nor any of their employees, makes any warranty, express or implied, or assumes any legal liability or responsibility for the accuracy, completeness, or usefulness of any information, apparatus, product, or process disclosed, or represents that its use would not infringe privately owned rights. Reference herein to any specific commercial product, process, or service by trade name, trademark, manufacturer, or otherwise, does not necessarily constitute or imply its endorsement, recommendation, or favoring by The Regents of the University of California, the United States Government, or any agency thereof. The viezs and opinions of authors expressed herein do not necessarily state or reflect those of The Regents of the University of Califormia, the United States Gooernment, or any agency thereof. Los Alamos National Laboratory strongly supports academic freedom and a researcher's right to publish; as an institution, hozpever, the Laboratory does not endorse the viewpoint of a publication or guarantee its technical correctness. 


\section{DISCLAIMER}

Portions of this document may be illegible in electronic image products. Images are produced from the best available original document. 
Fuels Inventories in the

Los Alamos National Laboratory Region: 1997

Randy G. Balice

Brian P. Oswald*

Charlie Martin**

*College of Forestry, Stephen F. Austin State University, P.O. Box 6109,

SFA Station, Nacogdoches, Texas 75962

**USDA Forest Service, Santa Fe National Forest, 1474 Rodeo Road,

Santa Fe, Nezw Mexico 87504

\section{Los Alamos}

NATIONAL LABORATORY

Los Alamos, New Mexico 87545 


\section{TABLE OF CONTENTS}

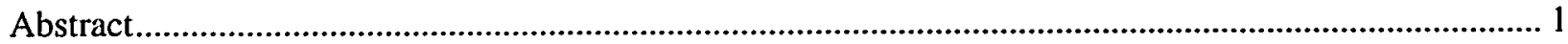

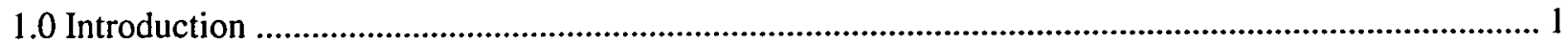

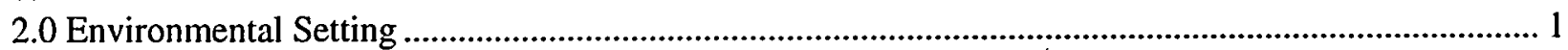

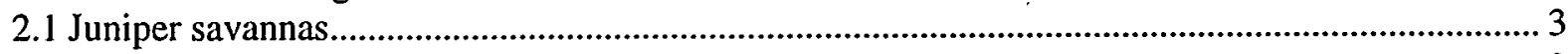

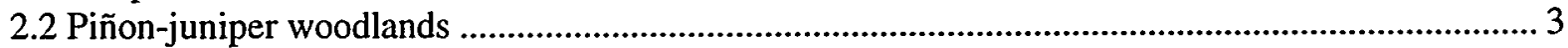

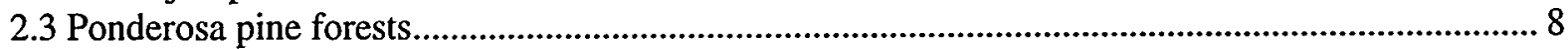

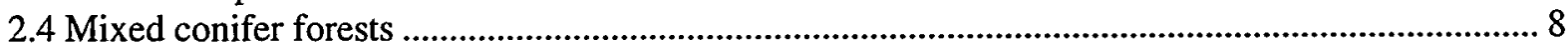

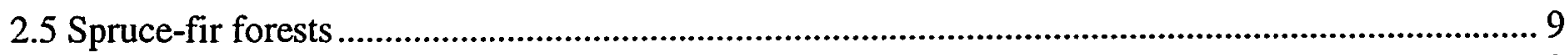

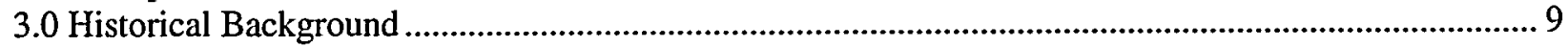

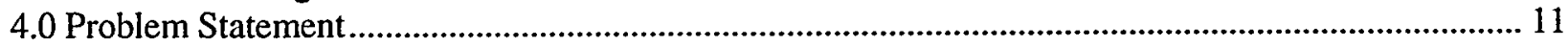

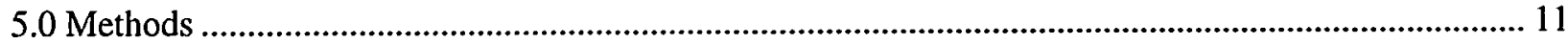

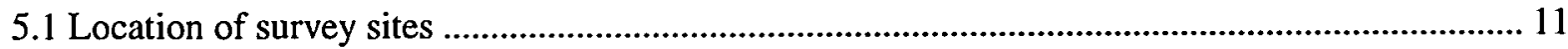

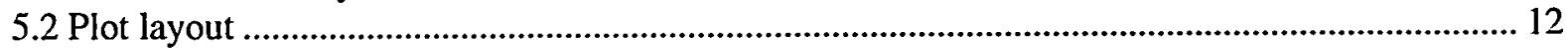

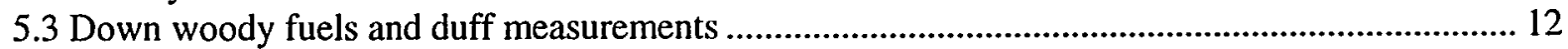

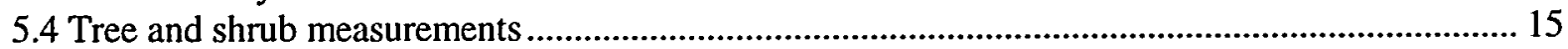

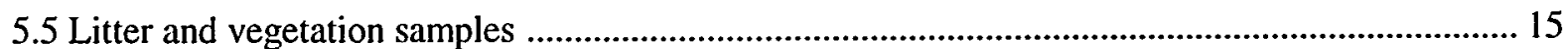

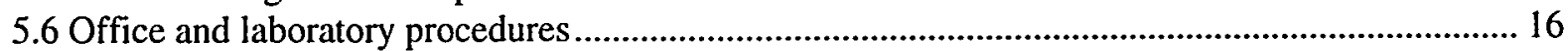

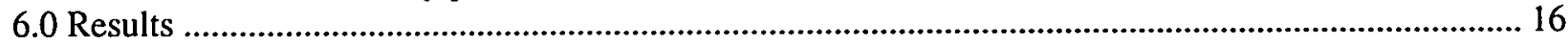

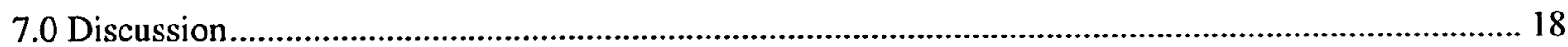

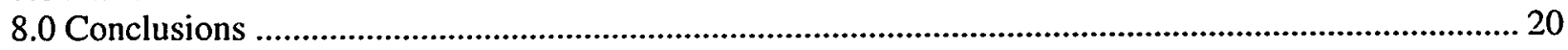

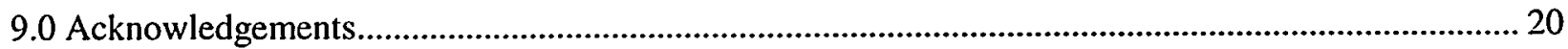

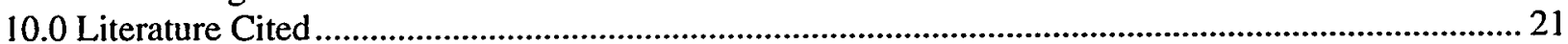

Appendix A: Summaries of Physical Characteristics and Overstory Data for

Fuels Inventory Sites Sampled in 1997 ............................................................................................ 23

Appendix B: Summaries of Understory Fuel Levels for Fuels Inventory Sites

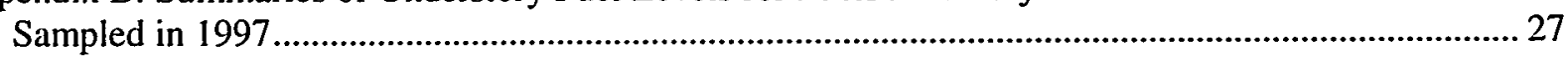

\section{List of Figures}

Figure 1. Location of Los Alamos National Laboratory and its surroundings ........................................... 2

Figure 2. Typical elevations in the Los Alamos region ............................................................................... 4

Figure 3. Selected land cover types in the Los Alamos region...................................................................5

Figure 4. Elevational ranges of selected land cover types ............................................................................. 7

Figure 5. Approximate locations of fuels inventory sample sites........................................................... 13

\section{List of Tables}

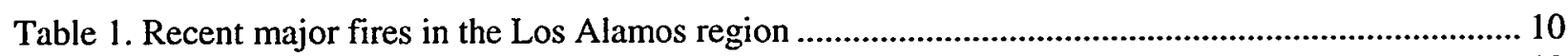

Table 2. Sample vegetational-topographic conditions................................................................. 12

Table 3. Size classes of down woody fuels .......................................................................................... 12

Table 4. Fuels inventory summaries and results of multivariate analyses................................................ 17

Table 5. Predicted flame lengths $(\mathrm{ft})$................................................................................................... 18

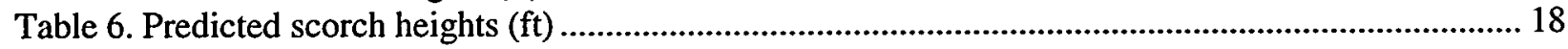




\title{
Fuels Inventories in the Los Alamos National Laboratory Region: 1997
}

\author{
Randy G. Balice, Brian P. Oswald, and Charlie Martin
}

\begin{abstract}
Fifty-four sites were surveyed for fuel levels, vegetational structures, and topographic characteristics. Most of the surveyed sites were on Los Alamos National Laboratory property, however, some surveys were also conducted on U.S. Forest Service property. The overall vegetation of these sites ranged from piñon-juniper woodlands to ponderosa pine forests to mixed conifer forests, and the topographic positions included canyons, mesas, and mountains. The results of these surveys indicate that the understory fuels are the greatest in mixed conifer forests and that overstory fuels are greatest in both mixed conifer forests and ponderosa pine forests on mesas. The geographic distribution of these fuels would suggest a "most credible wildfire scenario" for the Los Alamos region. Three major fires have occurred since 1954 and these fires behaved in a manner that is consistent with this scenario. The "most credible wildfire scenario" was also supported by the results of BEHAVE modeling that used the fuels inventory data as inputs. Output from the BEHAVE model suggested that catastrophic wildfires would continue to occur during any season with sufficiently dry, windy weather.
\end{abstract}

\subsection{Introduction}

The Los Alamos National Laboratory (LANL) and its surrounding region have been increasingly threatened by the potential occurrence of catastrophic fires. To more clearly understand this potential, a preliminary sample survey was conducted from June through August of 1997 to assess the fuels in forests and woodlands at or near LANL. The results of this preliminary survey are summarized and evaluated in this report.

The purpose of this project is to inventory selected sample locations that represent a range of environmental conditions. The resulting sample provides a preliminary estimate of the fuel levels on LANL and in its surroundings, the Los Alamos region. This effort was constrained by the inaccessibility of certain areas. Given this constraint, the overall goal of the project is to provide preliminary data that can be utilized to evaluate the hazards from wildfire in the Los Alamos region.

\subsection{Environmental Setting}

LANL covers $112 \mathrm{~km}^{2}\left(43 \mathrm{mi}^{2}\right)$ of land. It is located on the eastern slopes of the Jemez Mountains, approximately $120 \mathrm{~km}(80 \mathrm{mi})$ north of Albuquerque and $40 \mathrm{~km}(25 \mathrm{mi})$ northwest of Santa Fe (Figure 1). LANL is largely but not completely circumscribed by Los Alamos County. In addition to LANL- and County-administered parcels, a significant portion of Los Alamos County is under the management of the U.S. Forest Service. LANL is also bordered on the south 


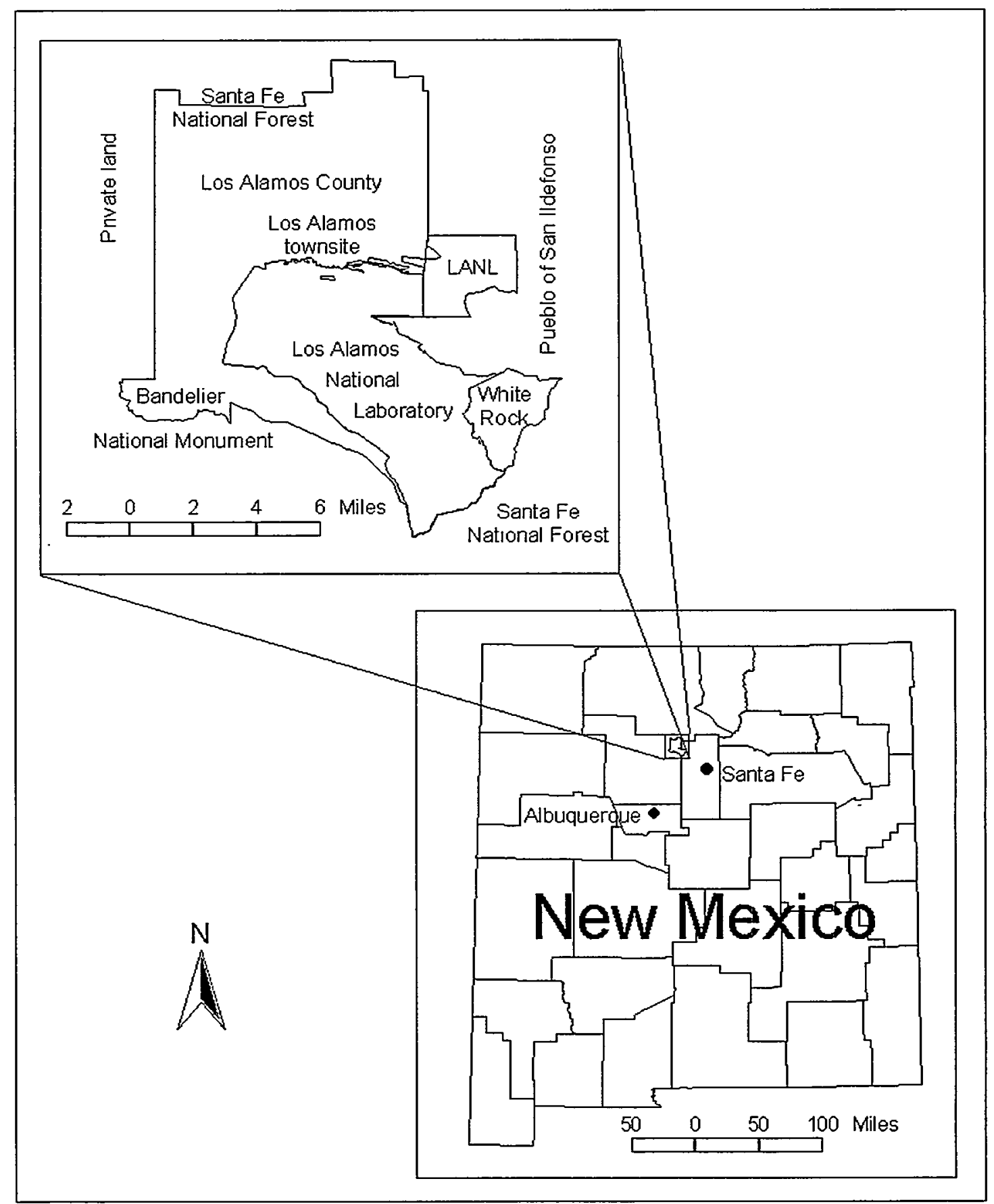

Figure 1. Location of Los Alamos National Laboratory and its surroundings. 
by the Bandelier National Monument and on the east by Pueblo of San Ildefonso lands. Two populated areas, Los Alamos townsite and White Rock townsite, are adjacent to LANL on the north and southeast, respectively.

The Los Alamos region, including LANL, Los Alamos County, and portions of Bandelier National Monument, spans an elevational gradient of approximately $1,631 \mathrm{~m}(5,350 \mathrm{ft})$, adjacent to the Rio Grande, to $3,199 \mathrm{~m}(10,496 \mathrm{ft})$ at its northwestern extremities (Figure 2). Within this gradient, the region of interest in this study was limited to forested and wooded areas at the middle elevations of LANL property and in the immediate surroundings. This consists primarily of forested or wooded mesas, canyons, and mountain slopes between the elevations of $1,920 \mathrm{~m}$ $(6,300 \mathrm{ft})$ and $2,743 \mathrm{~m}(9,000 \mathrm{ft})$.

The elevational gradient in the LANL region encompasses five major vegetational zones (Figure 3). These include juniper savannas, piñon-juniper woodlands, ponderosa pine forests, mixed conifer forests, and spruce-fir forests (Balice et al. 1997). Each of the five major vegetational zones is briefly described in the following paragraphs, and their elevational ranges are summarized in Figure 4. For reference purposes, the elevational ranges of aspen forests are also shown in Figure 4.

\subsection{Juniper savannas}

Juniper savannas constitute the dominant upland vegetation type at the lowest elevations in the LANL region (Foxx and Tierney 1984). Juniper savannas can be found near the Rio Grande from $1,634 \mathrm{~m}$ to $1,681 \mathrm{~m}(5,360 \mathrm{ft}$ to $5,513 \mathrm{ft})$ and extending upwards in adjacent canyons to approximately $1,768 \mathrm{~m}(5,800 \mathrm{ft})$ above mean sea level (Foxx and Tierney 1980, Balice et al. 1997).

Juniper savannas are mostly open communities with widely scattered trees and grassy understories. One-seed juniper (Juniperus monosperma) is the dominant tree species. Other tree species, such as piñon (Pinus edulis), may also be present, but their combined canopy coverage is less than 5 percent.

Understories within juniper savanna communities are typically dominated by grass species such as side-oats grama (Bouteloua curtipendula). Blue grama (Bouteloua gracilis) and hairy grama (Bouteloua hirsuta) are also widely distributed and may be present as codominant species. Cane cholla (Opuntia imbricata) and other shrubs may also be scattered throughout these communities.

\subsection{Piñon-juniper woodlands}

Although piñon-juniper woodlands can extend to as low as $1,676 \mathrm{~m}(5,500 \mathrm{ft})$, they are the dominant community type between $1,768 \mathrm{~m}$ and $2,134 \mathrm{~m}(5,800 \mathrm{ft}$ and $7,000 \mathrm{ft})$ in elevation (Foxx and Tierney 1980, Balice et al. 1997). They also can be found as high as 2,195 $\mathrm{m}$ (7200 ft) on southerly facing exposures. 


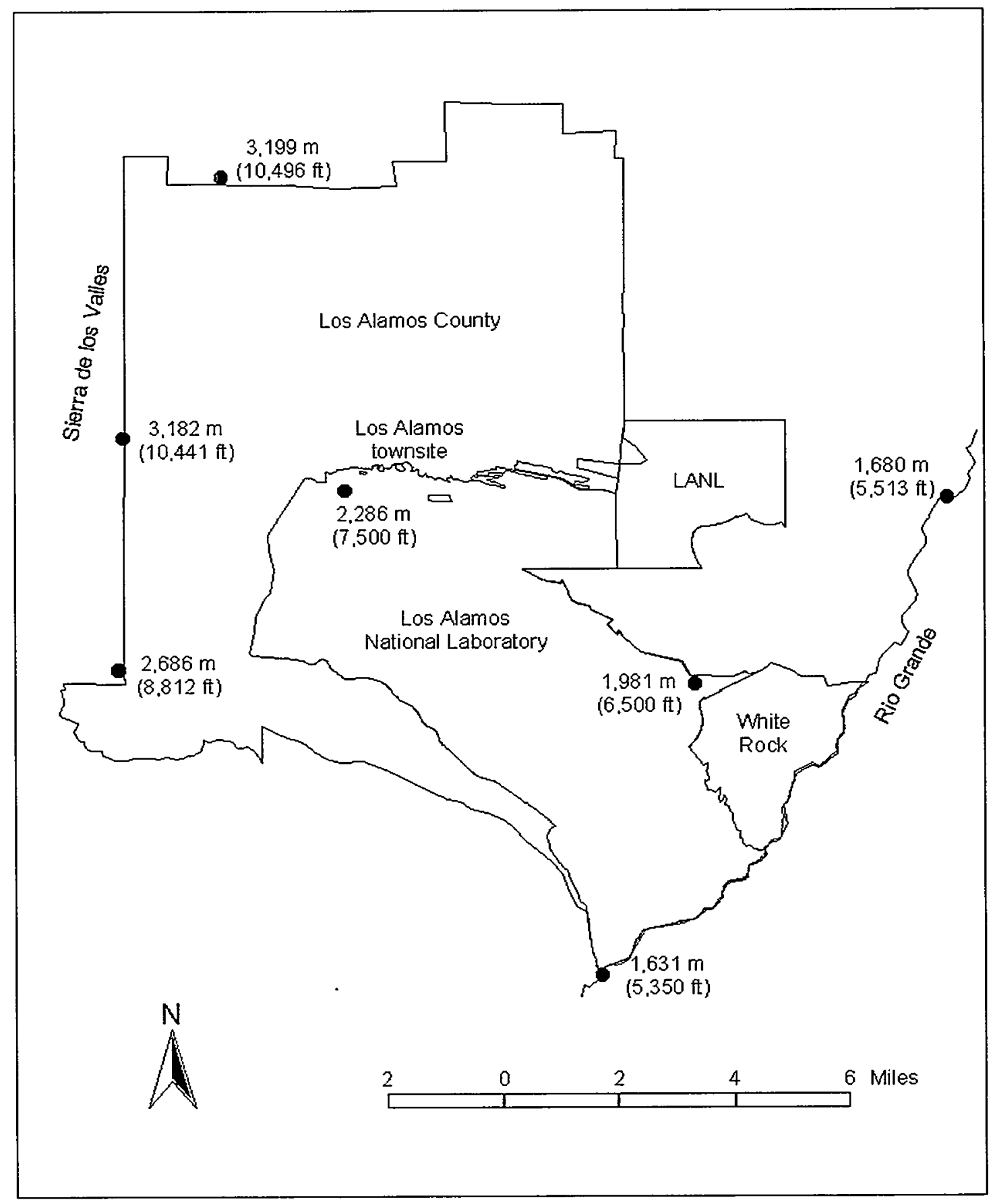

Figure 2. Typical elevations in the Los Alamos region. 


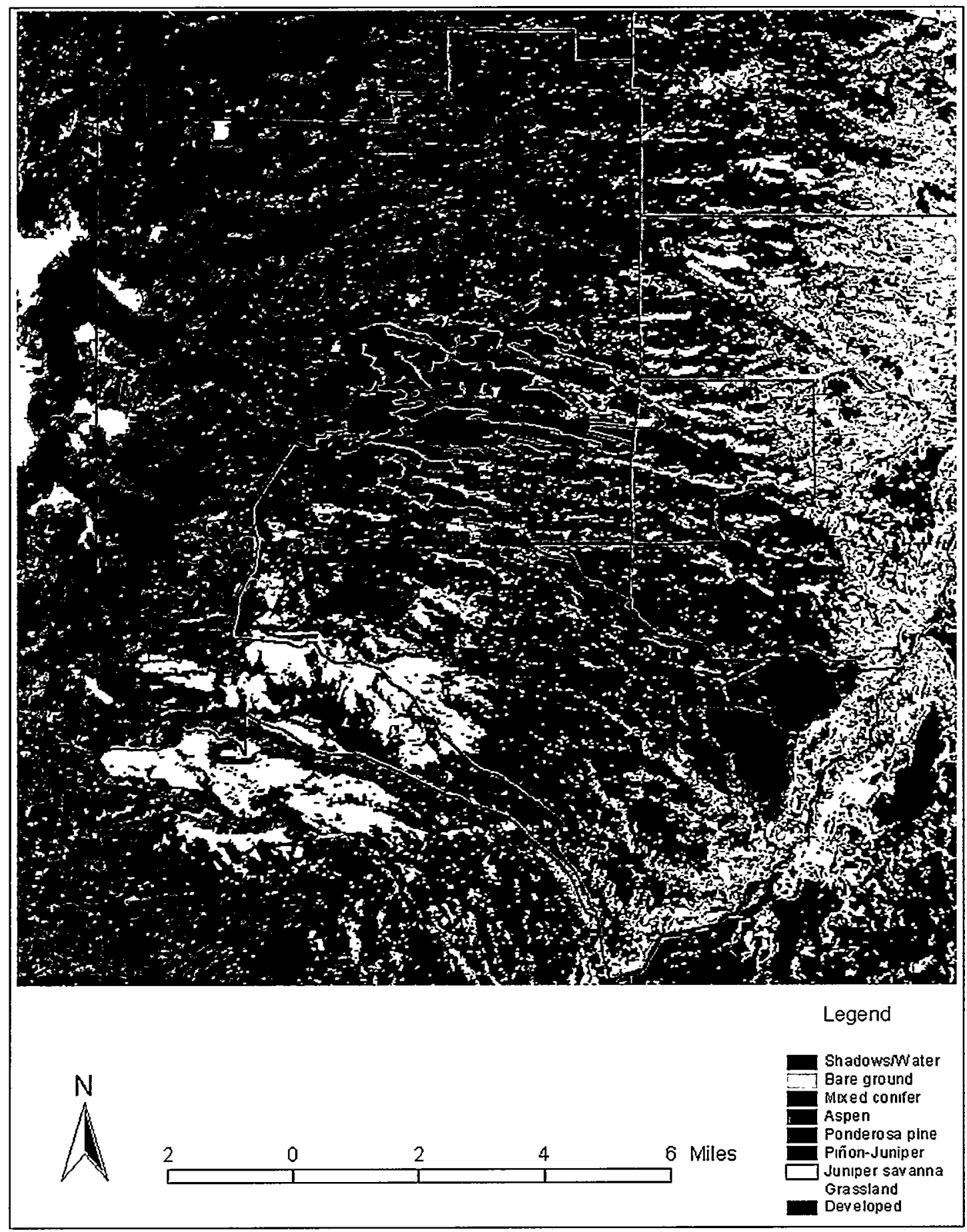

Figure 3. Selected land cover types in the Los Alamos region. Source: Koch et al. 1997. 



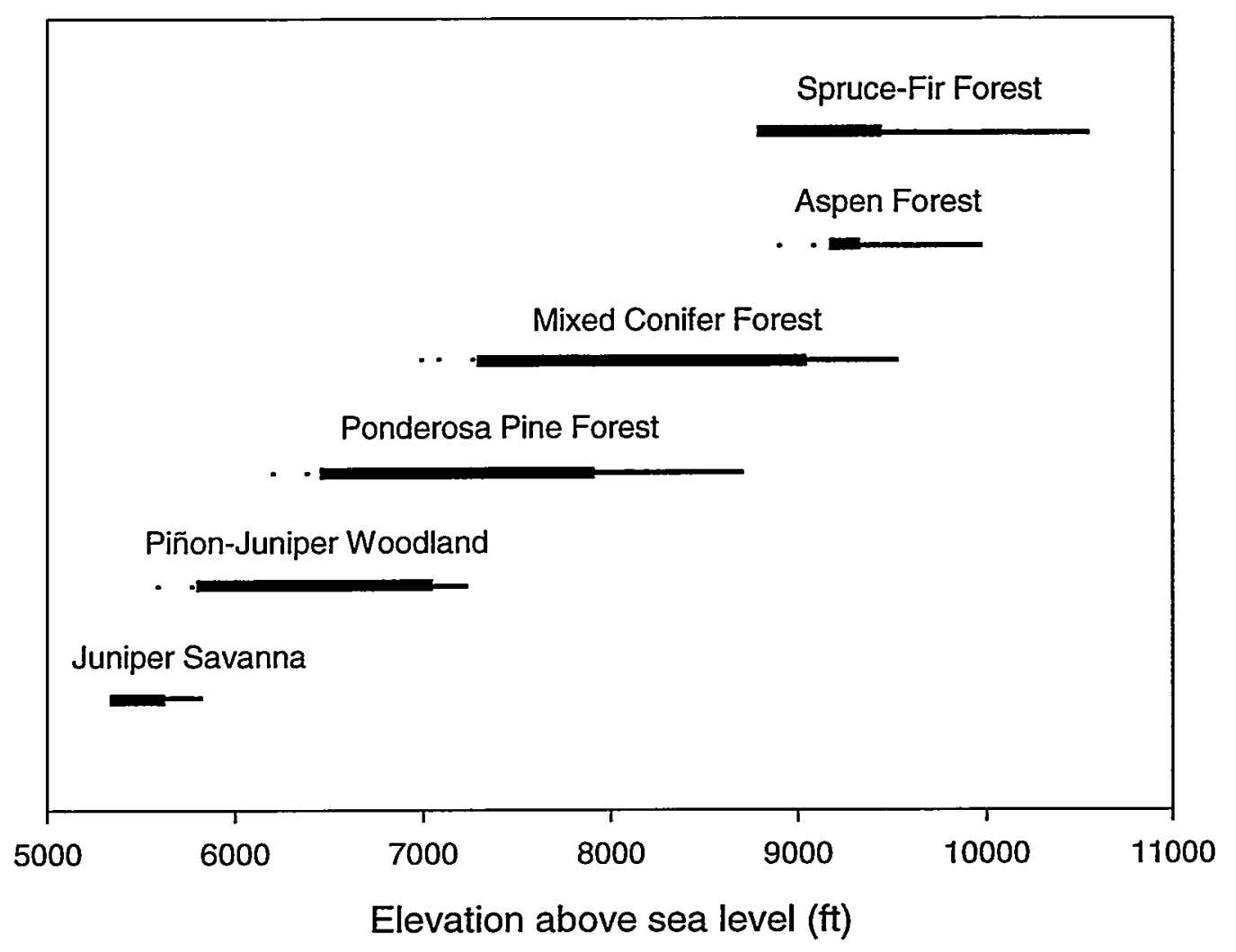

$\ldots$ North-facing exposures
Level terrain
South-facing exposures

Figure 4. Elevational ranges of selected land cover types. 
Piñon-juniper woodlands range from open-canopied to closed-canopied communities (Foxx and Tierney 1984; Balice et al. 1997). The dominant tree species are one-seed juniper or piñon. The relative dominance between these two species depends on the elevation. Within the range of these woodlands, one-seed juniper is more abundant at lower elevations, while piñon is more abundant at higher elevations. Other tree species are absent or rare.

Piñon-juniper woodlands are patchy communities where the understories are dominated by an assortment of grasses and shrubs. Typical graminoid dominants include mountain muhly (Muhlenbergia montana) and blue grama. In the shrub layer, oaks (Quercus gambelii and $Q$. undulata) and mountain mahogany (Cercocarpus montanus) are common species.

\subsection{Ponderosa pine forests}

Ponderosa pine forests extend to as low as $1,890 \mathrm{~m}(6,200 \mathrm{ft})$ in some of the protected canyons in the LANL region (Foxx and Tierney 1980, Balice et al. 1997). At these lower extremities ponderosa pine forests intergrade with piñon-juniper woodland. On the mesas and the lower slopes of the Sierra de Los Valles, ponderosa pine forests extend to $2,377 \mathrm{~m}(7,800 \mathrm{ft})$ in elevation. They may also be found at higher elevations on steep, south-facing slopes.

This cover type is an open or closed forest. Ponderosa pine (Pinus ponderosa) is the dominant tree species. One-seed juniper and piñon may also be present, particularly at lower elevations, but other tree species are typically absent or rare. At higher elevations, Douglas fir (Pseudotsuga menziesii) and Rocky Mountain juniper (Juniperus scopulorum) can be found in ponderosa pine forests. Douglas fir may be especially common in areas that were protected from wildfires for prolonged periods.

The understories in the ponderosa pine zone are typically shrubby, with significant amounts of graminoid species also being present. Gambel oak (Quercus gambelii) and Colorado barberry (Berberis fendleri) are common associates in the shrub stratum. The most abundant graminoid species include White Mountain sedge (Carex geophila), mountain muhly, little bluestem (Schizachyrium scoparium), and pine dropseed (Blepharoneuron tricholepis).

\subsection{Mixed conifer forests}

Mixed conifer forests begin as intergrades with ponderosa pine communities and as stringers on north aspects of the canyons above $2,103 \mathrm{~m}(6,900 \mathrm{ft}$ ) in elevation (Foxx and Tierney 1980, Balice et al. 1997). These communities continue to $2,743 \mathrm{~m}(9,000 \mathrm{ft})$ on eastern exposures and on flat topographic positions. On southern exposures, mixed conifer forests extend to $2,896 \mathrm{~m}$ $(9,500 \mathrm{ft})$.

Douglas fir and white fir (Abies concolor) are the typical overstory dominants in mixed conifer forests. Ponderosa pine is also typically present. Frequently this species is represented by remnants from previous, open-canopied forest stands and by numerous pole-sized trees that have become established after 1890. Limber pine (Pinus flexilis) can also be found, especially on rocky ridgeline positions. 
The understories in the mixed conifer forests are extremely variable. Shrubs, including ninebark (Physocarpus monogynous), kinnikinnik (Arctostaphylos uva-ursi), Gambel oak, wild rose (Rosa woodsii), cliffbush (Jamesia americana), Oregon grape (Mahonia repens), myrtle boxleaf (Pachystima myrsinites), mountain maple (Acer glabrum), and dwarf juniper (Juniperus communis), are found along with numerous species of herbs and graminoids. Among the grasses and grasslike species, White Mountain sedge, nodding brome (Bromus anomalus), and muttongrass (Poa fendleriana) are the most commonly found.

\subsection{Spruce-fir forests}

Spruce-fir forests can be found on north aspects as low as 2,682 $\mathrm{m}(8,800 \mathrm{ft})$ and on more exposed slopes as low as 2,819 $\mathrm{m}(9,250 \mathrm{ft})$ in the Sierra de los Valles (Foxx and Tierney 1984; Balice et al. 1997). These communities extend to the highest elevations of the Sierra $(3,199 \mathrm{~m}$ $[10,496 \mathrm{ft}])$.

Engelmann spruce (Picea engelmannii) and subalpine fire (Abies lasiocarpa) are typically the dominant tree species, although Douglas fir and white fir may also be abundant. Aspen (Populus tremuloides) is also a major overstory species, especially on south-facing slopes above $2,683 \mathrm{~m}$ $(8,800 \mathrm{ft})$ that had been burned in recent decades.

The understories in the spruce-fir forests are typically shrubby and herbaceous. Shrubs are represented by mountain maple, cliffbush, ninebark, myrtle boxleaf, and whortleberry (Vaccinium myrtillus). Among the herbaceous species, Arizona peavine (Lathyrus arizonicus), sidebells (Pyrola secunda), false Solomon's seal (Smilacina racemosa), forest fleabane (Erigeron eximius), rattlesnake plantain (Goodyera oblongifolia), and Fendler meadowrue (Thalictrum fendleri) are commonly found. Nodding brome is the only graminoid species that is widely distributed in the spruce-fir zone. In general, grasses are not abundant except where aspen dominates the overstory.

\subsection{Historical Background}

The history of European peoples in the region that is now LANL is relatively brief. Before the 1890s, the entire Jemez Mountains was a wilderness where natural ecological forces, including fire, were integral components of the landscape (Allen 1989). Wildland fires were frequent events in this pre-European setting. However, most of these fires burned on the surface of the ground and were of low intensities, causing little damage to the forest canopies.

With the nearby arrival of the railroads in 1888, the natural resources of the LANL region became exploitable for timber and sheep grazing. However, the era of forestry and grazing in the Los Alamos region was short lived and was replaced by small-scale to medium-scale farming in the early 1900s. These farms were established throughout the middle elevations of the.region. As a group, these activities interrupted the natural fire cycle by removing the overstory and understory fuels that are required to sustain fires.

In December of 1942, all logging, grazing, and farming activities in the LANL region were terminated by the establishment of a military research installation, known as the Manhattan 
Project. This was the precursor of LANL, and from these relatively modest beginnings, LANL developed into a major facility for the Department of Energy. To support LANL, residential and business districts were established at the Los Alamos and White Rock townsites.

Because of its geographic locality, much of LANL and the adjacent Los Alamos townsite are intermixed or interfaced with forests and woodlands. In an effort to maintain these forests and woodlands as a security buffer, they were passively managed throughout much of the last 55 years. This passive management, combined with the near absence of wildland fires since the 1880 s, has fostered natural growth and developmental changes, and the result of these changes has been the progressively increased potential for these sylvan environments to support catastrophic fires.

The results that were produced by the interruption of the natural fire cycle were unexpected. Before 1890 , forest vegetation in the LANL region consisted of a few, widely spaced trees that were large in size. Underneath these trees, the ground cover was predominated by grasses and sedges. Shrubs, saplings, and small trees were not abundant. This combination of vegetational conditions was maintained and perpetuated by the pre-1890 fire cycle.

In the absence of repeated fires, the vegetation in the LANL region slowly developed into the forest structures that are familiar today. These are characterized by numerous, closely-spaced trees that range in size from saplings to mature individuals. In many places, shrubs and tree seedlings are dense. In other places, the dense tree canopies preclude understory growth altogether. As a result of this unchecked vegetational growth, forests at LANL have become prone to fires that destroy the forests rather than perpetuate them.

This shift from numerous, low-intensity fires to infrequent, high-intensity fires is significant because the latter type of fire can produce catastrophic consequences to ecosystems and to human facilities and developments. This fact is evidenced by the occurrence of three large fires in the Los Alamos region in recent decades (Table 1).

The first of these catastrophic fires occurred in early June of 1954 (The New Mexican, 1954). It was started by an attempt to burn trash and construction debris in the upper Water Canyon area. Because of winds up to 72 kilometers per hour ( 45 miles per hour), the trash fire quickly spread to the adjacent forests. In the ensuing days, the fire swept to the north along a swath up to one mile in width. Fire fighters from Los Alamos constructed firebreaks with bulldozers, but they were unable to contain the blaze.

Table 1. Recent major fires in the Los Alamos region.

\begin{tabular}{|c|c|c|}
\hline Name & Start Date & $\begin{array}{c}\text { Area Burned } \\
\text { hectares (acres) }\end{array}$ \\
\hline Water Canyon Fire & $\sim$ June 6, 1954 & $\sim 1,200(\sim 3,000)$ \\
\hline La Mesa Fire & June 16, 1977 & $6,108(15,270)$ \\
\hline Dome Fire & April 25, 1996 & $6,606(16,516)$ \\
\hline
\end{tabular}

Finally, the winds abated and the fire intensity reduced to manageable levels at a distance of about $6 \mathrm{~km}(4 \mathrm{mi})$ from its origination. 
The second catastrophic fire to strike the Los Alamos region, the La Mesa Fire, was first reported on June 16, 1977 (Foxx 1984). It started less than $6 \mathrm{~km}$ (4 mi) southwest of Los Alamos, and it was determined that the fire was caused by humans. In spite of heroic efforts to suppress it, the fire swept through 6,180 ha $(15,270 \mathrm{ac})$ of ponderosa pine forests that included southern portions of LANL. As a result of changing weather conditions and an abatement of high winds, the fire was finally subdued on June 23.

The third catastrophic fire, the Dome Fire, arose from an abandoned campfire approximately $8 \mathrm{~km}(5 \mathrm{mi})$ to the southwest of LANL (Balice 1996). The fire was discovered in the afternoon of April 25, 1996, and burned for eight days before moderating weather conditions allowed for its suppression. The fire burned 6,684 hectares (16,516 acres) of forests and threatened the southwestern portions of LANL, although it did not cross on to LANL property.

None of these fires caused major damage to LANL facilities, nor did they consume residential areas in the Los Alamos townsite. However, LANL facilities were threatened and LANL programs were interrupted during these fires. Furthermore, none of these fires were terminated by active suppression activities. In spite of intensive efforts to suppress these fires, they each burned intensely for about one week and became manageable only after the air temperatures and the wind speeds decreased and the humidity of the atmosphere increased. During the time since these fires occurred, the threat from catastrophic fires to LANL programs and facilities has not abated. In fact, as forests continue to grow and develop each year, the threat of wildfire increases.

\subsection{Problem Statement}

The existence of altered forest structures in the Los Alamos region and the occurrence of infrequent, catastrophic wildfires instead of frequent, low-intensity fires presents a problem for the local populace. Ultimately, it is inevitable that these wildfires will destroy major facilities at LANL or residential areas in the Los Alamos townsite unless vigorous, emergency mitigation measures are taken. The only mitigation measures that would be effective in the control of wildland fire hazards is to reduce the amount of fuels in the forests and woodlands. Therefore, the purpose of this project is to support the design of optimal fuels reduction strategies by conducting a preliminary survey of selected vegetational-topographic combinations to determine the relative intensities and spatial distributions of forest fuels.

\subsection{Methods}

\subsection{Location of survey sites}

Fifty-four sample sites were subjectively selected (Figure 5). Each of these sample sites was required to be approximately 0.2 hectare $(0.5 \mathrm{acre})$ in size and relatively homogeneous with respect to vegetation structures, soils, and topography. The intention of this selection process was to span the ranges of topographic features and the forested or wooded conditions in the LANL region that are between the elevations of $1,920 \mathrm{~m}(6,300 \mathrm{ft})$ and $2,743 \mathrm{~m}(9,000 \mathrm{ft})$. The topographic positions included in this study are mesas, canyons, and mountain slopes. With respect to the major vegetational zones, or Level I cover types, at LANL, this collection of 
sample sites includes the three major cover types in the Los Alamos region-piñon-juniper woodlands, ponderosa pine forests, and mixed conifer forests (Table 2).

Table 2. Sampled vegetation-topographic combinations.

\begin{tabular}{|l|c|c|c|c|}
\hline & \multicolumn{3}{|c|}{ Topography } & \\
\hline Vegetation type & Canyon & Mesa & Mountain & Total \\
\hline Piñon-Juniper & 8 & 7 & NA & 15 \\
\hline Ponderosa pine & 5 & 23 & NA & 28 \\
\hline Mixed conifer & 6 & NA & 5 & 11 \\
\hline Total & 19 & 30 & 5 & 54 \\
\hline
\end{tabular}

$N A=$ This combination was not found in the sample region.

\subsection{Plot layout}

At each sample location, the center was marked. The UTM coordinates of this center were recorded with a global positioning system.

From the plot center, a circular series of radiating lines was established. Each line was $50 \mathrm{ft}$ in length ${ }^{1}$. Using a compass with the declination set at 11 degrees, the first line was oriented from the center of the plot to true north. Then, 15 additional lines were located at 22.5-degree intervals in a clockwise direction so that they radiated outward from the center point. To avoid excessive sampling near the center point, the lines began at two different distances from this central location. The odd-numbered lines began at $10 \mathrm{ft}$ and continued to a distance of $60 \mathrm{ft}$ from the center point. Even-numbered lines began at $30 \mathrm{ft}$ and continued to $80 \mathrm{ft}$.

\subsection{Down woody fuels and duff measurements}

Fuel sampling follows the general procedure described by Brown et al. (1982). Woody fuels that were on the ground were counted or measured if they intercepted the lines. To facilitate sampling and subsequent analyses of fire behaviors, these down woody fuels were subdivided into four size classes (Table 3).

Table 3. Size classes of down woody fuels.

\begin{tabular}{|l|l|}
\hline Fuel type & \multicolumn{1}{|c|}{ Size class } \\
\hline 1 hour & less than $1 / 4$ inch in diameter \\
\hline 10 hour & $1 / 4$ inch to 1 inch in diameter \\
\hline 100 hour & 1 inch to 3 inches in diameter \\
\hline 1,000 hour & greater than 3 inches in diameter \\
\hline
\end{tabular}

The fuel type designation reflects the time required for the fuel moisture to equilibrate with ambient atmospheric conditions.

According to their size class, these woody fuels were sampled at varying positions along the lines. Tallies of 1-hour fuels and 10-hour fuels were completed at the first $6 \mathrm{ft}$ of each line. Tallies of 100-hour fuels were completed in the first $10 \mathrm{ft}$ of the lines. The 1,000-hour fuels

\footnotetext{
${ }^{1}$ English units of measurement were used throughout this study.
} 


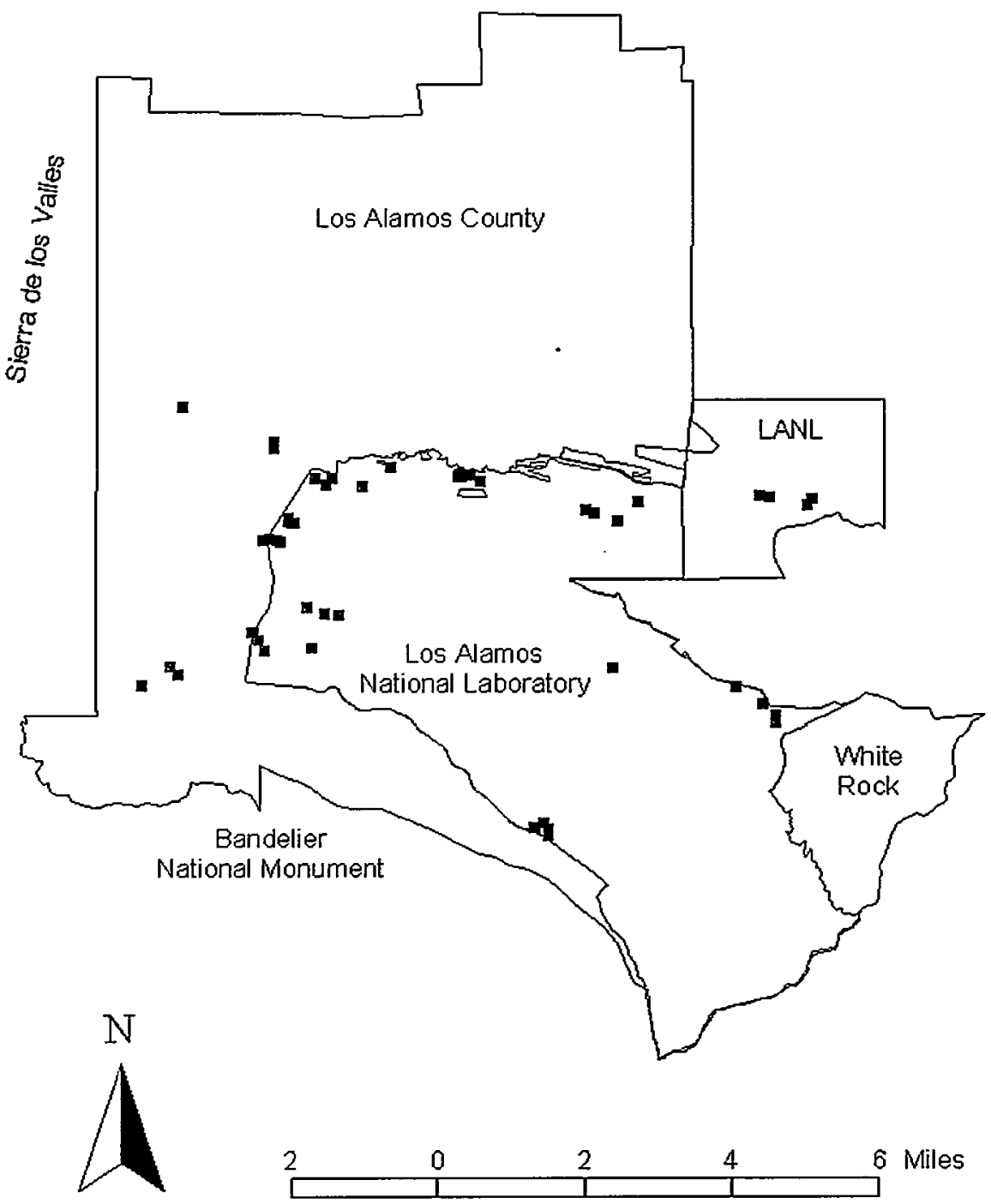

Figure 5. Approximate locations of fuels inventory sample sites. 

were sampled along the entire length of the lines, $50 \mathrm{ft}$. The amount of intercept between the 100-hour fuels and the line were recorded, to the nearest tenth of an inch. The condition of the 100-hour fuels, sound or rotten, was also noted.

Duff depths were measured at distances of $1 \mathrm{ft}$ and $6 \mathrm{ft}$ from the beginning of each line. This was done by inserting a ruler into the layer of duff and measuring its thickness to the nearest tenth of an inch.

\subsection{Tree and shrub measurements}

Trees less than $10 \mathrm{ft}$ in height were sampled in 1/300-acre plots (Brown et al. 1982). These plots, with a radius of $6.8 \mathrm{ft}$, were located at the initial starting point of each line. This resulted in a total of $161 / 300$-acre plots. Within each plot, all trees were recorded by species and measured for their total heights and diameters. The diameters were measured at $4.5 \mathrm{ft}$ above ground for any tree that was at least 1 inch in diameter at that height. For trees that were smaller than this, the diameter was measured at ground level. The total heights were measured to the nearest foot and the diameters were measured to the nearest tenth of an inch.

Trees greater than $10 \mathrm{ft}$ tall were censused in a one-quarter acre, square plot (104.4 ft by $104.4 \mathrm{ft}$ ) that was centered on the plot center. The census plot was oriented with the cardinal directions. Each tree was recorded by species, diameter at breast height (DBH) in inches, total height in feet, height from the ground to the lowest live crown in feet, and crown class. The crown class was categorized as dominant, codominant, intermediate, or suppressed. For some of the higher elevation plots, a crown weight adjustment factor (CWAF) was used in place of total height, height to live crown, and crown class. The CWAF tree crown density rating begins with four as a full crown and ends with one as less than one-quarter of a full crown. All other values that range between one and four represent intermediate crown densities.

Shrubs were sampled in 3.14- $\mathrm{ft}^{2}$ plots (Brown et al. 1982). Two shrub sample plots were established by placing their centers at a distance of $6.8 \mathrm{ft}$ and perpendicular to the respective line, one plot to each side of the line. For 16 lines, this resulted in a total of 32 plots. The radius of each plot was $1 \mathrm{ft}$. Shrubs within the plot were measured for total height and at ground level for stem diameter.

\subsection{Litter and vegetation samples}

Litter samples were collected within rectangular or square plots (Brown et al. 1982). Four rectangles, each with an area of $2 \mathrm{ft}^{2}$, were used for this purpose and located with respect to the line that was oriented toward true north. Dimensions of the rectangles are $1 \mathrm{ft}$ by $2 \mathrm{ft}$. One rectangle each was placed at the $16-\mathrm{ft}$ mark and $24-\mathrm{ft}$ mark of the line so that their axis was perpendicular and to the east of the line. The two additional rectangles were placed at the same distance along the line and in the same orientation, although they were positioned at a distance of $4 \mathrm{ft}$ from the line rather than adjacent to it.

Once the rectangles had been placed at their respective locations, the litter and understory vegetation were independently rated within each one. The rectangle with the greatest amount of 
vegetation was exhaustively sampled, and the material was placed in a labeled bag for drying. The plant biomass within each of the remaining three rectangles was estimated as a percent of the total amount of vegetation contained in the sampled rectangle. This percentage was recorded on the data sheets.

To obtain litter samples, the process of rating the rectangles was repeated. The rectangle with the greatest amount of litter was exhaustively sampled. The collected litter was placed in a labeled bag. The amount of litter in the remaining three rectangles was recorded as a percentage of the maximum amount.

\subsection{Office and laboratory procedures}

The litter and vegetation samples were dried for 24 hours at 65 degrees $\mathrm{C}$. They were weighed, and the data were entered into spreadsheet files. The litter and vegetation weight data were converted to tons per acre.

All of the field data were entered into spreadsheet files. The fuel load tonnages and numbers of trees were transformed to a per-acre basis. These data were summarized by vegetation type and by topographic position.

The results were analyzed with BEHAVE, a fire behavior prediction model (Andrews 1986, Andrews and Chase 1989). The intent was to predict the fire behavior of selected vegetation types in the Los Alamos region. These predictions will be useful for determining the relative fire hazards in the region and for assigning mitigation action strategies that will be required to protect these facilities.

\subsection{Results}

The data representing the site information and overstory structures for the 54 sample locations are presented in Appendix A. For convenience, these data are subdivided into individual tables, one for each vegetation and topographic condition. The columns of each table in Appendix A reference plot numbers, elevation (ft), slope (\%), aspect (degrees), exposure rating, overstory canopy coverage (\%), average height of the canopy, average distance from the ground to the lowest crown position, trees per acre $(>3$ in. $\mathrm{DBH})$, trees per acre ( 3 in. to 8 in. $\mathrm{DBH})$, and trees per acre $(>8$ in. $\mathrm{DBH})$. The individual plots were numbered sequentially by land ownership. The plot number prefix "LFI" indicates that the plot was located on LANL property, whereas the plot number prefix "FFI" indicates that the plot was located on U.S. Forest Service property. Note that a total of 45 and 9 plots were sampled on LANL and Forest Service lands, respectively. The exposure rating (Exp) is a numerical combination of slope percent (slope) and aspect in degrees (aspect), where 190 degrees is set to zero. The resultant exposure rating (Exp) ranges from -1 to 1 , according to the following equation:

$$
\operatorname{Exp}-\cos (\pi *(\text { aspect }-190) / 180) * \text { slope. }
$$


To calculate the average height of the overstory canopy, the 10 tallest trees were used, unless the tallest one or two trees were greater than 10 percent taller than the next tallest tree, in which case these outlier trees were ignored in the calculation. All trees in the sample were used to calculate the average distance from the ground to the lowest crown position. Finally, the overall means, standard deviations, standard errors, and coefficients of variation in percent are also given for each column of data, as applicable.

The understory fuels summaries for each plot are listed in Appendix B. The data in Appendix B are grouped into tables, one for each vegetation type and topographic condition. Within each table, the columns list weights (tons per acre) for 1-hour fuels, 10-hour fuels, 100-hour fuels, 1,000-hour fuels that are sound, 1,000-hour fuels that are rotten, duff, litter, live herbaceous vegetation, and the totals for each plot. The means, standard deviations, standard errors, and coefficients of variation in percent are also given for each column of data, as applicable.

To provide an exploratory data analysis of the results, the understory fuels weights and the overstory tree-per-acre data were analyzed, by vegetation and topographic class, with multivariate analysis of variance, followed by Duncan's multiple range tests. The results of these analyses are shown in Table 4. The independent variables are listed in the left-hand column of Table 4; the dependent variables are listed in the first row. The bold-type values in the shaded cells of Table 4 are significantly different from other cells in the column (P-value $\leq$ 0.05).

Table 4. Fuels inventory summaries and results of multivariate analyses.

\begin{tabular}{|l|c|c|c|c|c|c|c|c|c|c|}
\hline $\begin{array}{c}\text { Veg-Topo } \\
\text { Class }\end{array}$ & $\mathbf{1 ~ h r}$ & $\mathbf{1 0 ~ h r}$ & $\mathbf{1 0 0} \mathbf{~ h r}$ & $\mathbf{1 K} \mathbf{~ h r ~ S}$ & $\mathbf{1 K} \mathbf{~ h r} \mathbf{R}$ & Duff & Litter & Veg & T/A <8 & T/A >=8 \\
\hline PJ-Canyon & 0.3 & 1.2 & 0.7 & 0.5 & 2.9 & 3.4 & 0.8 & $\mathbf{0 . 0 3}$ & 46.4 & 25.9 \\
\hline PJ-Mesa & 0.3 & 1.6 & 0.9 & 1.6 & 2.0 & 3.6 & 1.7 & $\mathbf{0 . 0 3}$ & 68.7 & 33.1 \\
\hline Pipo-Canyon & 0.2 & 1.9 & 0.7 & 0.4 & 4.4 & 9.7 & 0.6 & 0.01 & 34.0 & 42.3 \\
\hline Pipo-Mesa & 0.2 & $\mathbf{2 . 3}$ & 0.9 & 1.3 & 6.7 & 8.5 & 0.9 & 0.01 & 52.5 & 91.0 \\
\hline MC-Canyon & $\mathbf{0 . 9}$ & $\mathbf{3 . 1}$ & $\mathbf{2 . 5}$ & 1.2 & $\mathbf{1 4 . 2}$ & $\mathbf{1 2 . 5}$ & 1.4 & 0.01 & $\mathbf{2 2 7 . 9}$ & $\mathbf{7 8 . 7}$ \\
\hline MC-Mountain & $\mathbf{0 . 6}$ & $\mathbf{2 . 0}$ & $\mathbf{3 . 4}$ & $\mathbf{3 . 2}$ & $\mathbf{2 8 . 6}$ & 9.1 & 0.7 & 0.01 & $\mathbf{2 2 2 . 1}$ & $\mathbf{1 2 1 . 8}$ \\
\hline
\end{tabular}

Data are organized by the independent variables: vegetation type (Veg) and by topographic characteristic (Topo). The vegetation types are as follows: $\mathrm{PJ}=$ piñon-juniper woodland, Pipo = ponderosa pine forest, and $M C=$ mixed conifer forest. The dependent variables in the top row include 1 -hr fuels, $10-\mathrm{hr}$ fuels, 100 -hr fuels, 1,000 -hr-sound ( $1 \mathrm{~K} \mathrm{hr} \mathrm{S)} \mathrm{fuels,} \mathrm{1,000-hr-rotten} \mathrm{(1K} \mathrm{hr} \mathrm{R)} \mathrm{fuels,} \mathrm{duff,} \mathrm{litter,} \mathrm{live} \mathrm{or} \mathrm{cured}$ herbaceous vegetation (veg), trees per acre that are less than $8 \mathrm{in} . \mathrm{DBH}(\mathrm{T} / \mathrm{A}<8)$, and trees per acre that are greater than or equal to 8 in. $\mathrm{DBH}(\mathrm{T} / \mathrm{A}>=8)$. The values for the down woody fuels and ground fuels are in tons per acre. Values in bold type in the shaded boxes are significantly different from values in the unshaded boxes within the same column ( $P$-value $<=0.05$ ).

Exploratory analyses were also performed on the data to determine the potential hazard during wildfires that they represent. The analyses selected combinations of vegetation type and fuel models (Anderson 1982) using the BEHAVE fire behavior prediction and fuel modeling system (Andrews 1986, Andrews and Chase 1989). The combinations included 1) piñon-juniper woodlands and Fuel Model 6,2) ponderosa pine forests and Fuel Model 9, and 3) mixed-conifer forests and Fuel Model 10. A variety of fuel moisture and weather conditions were specified for these analyses, including 1-hour fuels moistures that ranged from 2 percent to 10 percent, and wind speeds that ranged from $12 \mathrm{mph}$ to $20 \mathrm{mph}$. The choice of 1 -hour fuel moisture and wind speed conditions was designed to bracket the weather conditions that were experienced during 
the Dome Fire of 1996. Throughout much of the time period when the Dome Fire was at its peak, the 1-hour fuel moistures ranged from 2 percent to 4 percent and the wind speeds ranged from $15 \mathrm{mph}$ to $25 \mathrm{mph}$. The predicted flame lengths $(\mathrm{ft})$ and crown scorch heights ( $\mathrm{ft}$ ) for this range of conditions are shown in Tables 5 and 6 , respectively.

Table 5. Predicted flame lengths ( $\mathrm{ft}$ ).

\begin{tabular}{|c|c|c|c|c|}
\hline $\begin{array}{c}\text { 1-hr moisture } \\
(\%)\end{array}$ & $\begin{array}{c}\text { Wind speed } \\
\text { (mi/hr) }\end{array}$ & P-J woodland & Pipo forest & MC forest \\
\hline 2 & 20 & 17.3 & 25.3 & 14.9 \\
\hline 2 & 12 & 12.5 & 16.5 & 10.7 \\
\hline 6 & 20 & 14.1 & 19.7 & 12.4 \\
\hline 6 & 12 & 10.2 & 12.9 & 8.9 \\
\hline 10 & 20 & 3.6 & 17.3 & 11.2 \\
\hline 10 & 12 & 3.6 & 11.3 & 8.0 \\
\hline
\end{tabular}

The range of fuel moistures and wind speeds include those observed during the Dome Fire. P-J = piñonjuniper, $\mathrm{Pipo}=$ ponderosa pine, and $\mathrm{MC}=$ mixed conifer.

Table 6. Predicted scorch heights (ft).

\begin{tabular}{|c|c|c|c|c|}
\hline $\begin{array}{c}\text { 1-hr moisture } \\
(\%)\end{array}$ & $\begin{array}{c}\text { Wind speed } \\
\text { (mi/hr) }\end{array}$ & P-J woodland & Pipo forest & MC forest \\
\hline 2 & 20 & 116 & 262 & 82 \\
\hline 2 & 12 & 95 & 163 & 68 \\
\hline 6 & 20 & 72 & 154 & 53 \\
\hline 6 & 12 & 61 & 100 & 45 \\
\hline 10 & 20 & 2 & 114 & 41 \\
\hline 10 & 12 & 5 & 76 & 36 \\
\hline
\end{tabular}

The range of fuel moistures and wind speeds include those observed during the Dome Fire. P-J = piñonjuniper, Pipo $=$ ponderosa pine, and $M C=$ mixed conifer.

\subsection{Discussion}

Although not conclusive, the results of this study provide a clearer picture of the fuels levels in the Los Alamos region. Sample sites were selected in three vegetation types. These include piñon-juniper woodlands, ponderosa pine forests, and mixed conifer forests. Three topographic positions, canyons, mesas and mountains, were also surveyed. Combinations of these vegetation and topographic conditions are typical environmental features of Los Alamos region.

These results indicate that the understory fuel loads are typically greatest in mixed conifer forests on both canyon and mountain positions (Table 4). This includes nearly all of the down woody fuel classes, as well as duff depths in canyons. Furthermore, all mixed conifer forests, along with ponderosa pine forests on mesas, also support the most dense overstory canopies. These fuels structures in high-elevation forests suggest the following general wildfire scenario that one could expect to occur with increasing probability as fuels desiccate during the peak of the fire season, April through July. 
1) Day 1: Ignition would occur in the forests above $8,000 \mathrm{ft}(2,438 \mathrm{~m})$ either from lightning or from human activities. In either case, the litter, duff, and other fuels on the ground surface would be ignited.

2) Days 2 and 3: Because of the presence of large amounts of surface fuels on the forest floor and because of the hot, dry weather conditions, the fire would maintain itself at low intensities for days. During this time period, the fire would smolder in the duff or burn lightly in the nearly continuous understory fuels.

3) Day 4: The already hot, dry weather conditions continue to deteriorate. As the air temperature rises, the atmospheric humidity decreases, and the wind speed increases, the ground fire would become more intense and move from the ground to the ladder fuels; that is, shrubs and trees that are less than 8 in. in diameter. Once in the ladder fuels, the fire would easily ignite the overstory crown canopies and grow into a crown fire.

4) Day 5: Once in the upper canopy of the forest, the behavior of the fire would be dictated by the current wind conditions. Since the prevailing winds during the April-to-July time period are from the southwest to the northeast, the crown fire would spread from the mountains toward the western perimeter of LANL and the Los Alamos townsite.

5) Days 6 through 8: By this time the fire would be raging through the forest crown. All attempts by local fire fighters to suppress the fire would be ineffective. Land managers would be reduced to observers who must merely watch the fire from a safe distance. LANL would be closed and the townsite population would be evacuated. Destruction of residential areas and LANL facilities would be highly likely under these conditions.

6) Day 9: The weather conditions moderate. As a result of the decreased air temperatures and wind speeds, the intensity of the wildfire would be reduced to levels that are low enough for safe and effective suppression activities to resume.

7) Day 10: The initial attack on the fire would have further reduced its intensity. Further suppression activities would be implemented and ultimately the fire would be declared under control. Mop-up activities would continue for another week.

Although this wildfire scenario is based on the data that was collected during this fuels inventory survey, the form of the data emphasizes that this is the most credible wildfire scenario. This scenario is also consistent with each of the three wildfires that have occurred recently in the Los Alamos region (Table 1). Each of these fires was ignited in the 8,500-ft elevation level and was started by human activities. Each fire elevated from a ground fire to the crown under hot, dry, and windy weather conditions. Each burned dangerously and erratically in the forest canopies 
for two to four days. During this time period, active suppression was impossible because of the danger to fire fighters presented by the fires. In each of these cases, suppression was only possible after moderating weather conditions provided a safe opportunity for an initial attack by fire fighters.

This wildfire scenario is also supported by results of the BEHAVE fire behavior model. Using weather and fuels moisture conditions that were typical of the Dome Fire in combination with the fuels inventory data collected as part of this inventory, BEHAVE computed the flame lengths and scorch heights that are reported in Tables 5 and 6, respectively. Noting that BEHAVE is designed to model the effects of ground fires only, this computer model predicted flame lengths up to $15 \mathrm{ft}$ and scorch heights up to $82 \mathrm{ft}$ in mixed-conifer forests. Flame lengths and scorch heights of this magnitude would easily and quickly elevate a ground fire to the overstory canopy. Once in the upper canopy of the forest, the crown fire would be dangerous and unpredictable.

\subsection{Conclusions}

Fuel levels and vegetational structures were inventoried at 54 sample plots located throughout the Los Alamos region. A wide variety of vegetation types and topographic conditions was included in this survey. The results indicate that the fuel levels, and thus the fire danger, are greatest in the ponderosa pine forests and mixed conifer forests. Most of these types of vegetation can be found at elevations above $7,000 \mathrm{ft}(2,134 \mathrm{~m})$. Preliminary modeling of the fire behavior that could be expected in these forests during weather conditions that are similar to the Dome Fire indicated that ground fires would quickly spread into the forest canopies and create catastrophic wildfires.

The results of this study emphasize the need to learn more about the high-elevation forests in the Los Alamos region. These environments have not been investigated in detail, and preliminary surveys for classification purposes have noted that the vegetational-environmental relationships are not well understood (Balice et al. 1997). Since these forests contain the greatest amounts of fuels, they present the highest potential for development of catastrophic fires from any ignition that occurs during dry, windy weather conditions.

The results of this study also suggest a possible approach for the mitigation of these wildfire hazards. Noting that the fire triangle consists of heat, fuels, and an ignition source, it is evident that fuel levels are the only element of this triangle that can be controlled. Fuels are represented by trees and other plants in the forests, and these components of the landscape can be

economically removed by applying a variety of treatment methods. However, heat is represented by hot, dry weather conditions, and ignition results from lightning or human activities. Neither of these components of the fire triangle is amenable to direct controls or to management alterations.

\subsection{Acknowledgements}

We would like to thank Robert Remillard of the Santa Fe National Forest for his financial support, as well as his assistance with the design and logistics of this project. Other members of 
the Santa Fe National Forest, including Bill Armstrong and Claudia Standish, also provided invaluable assistance and support.

We would also like to acknowledge the Arthur Temple College of Forestry, Stephen F. Austin State University for providing additional financial assistance and support of the summer students. These students, Dana Beck, Josh Phillips, and Kelly Scott, performed the fieldwork. In addition, Dana Beck transferred the data from the field forms to computer files. Kelly Scott performed the laboratory preparatory work for the duff and litter analysis and converted the original data from counts to weights.

Many individuals and groups at LANL were instrumental in the success of this project. In particular, Robin Justice of FE-20 provided logistical support for work conducted on LANL property. In addition, Jim Stapleton and Peter Veverka assisted with access and escorting issues at S-Site.

Finally, we would like to acknowledge John Huchton and the Ecology Group (ESH-20) for providing support for the design and supervision of this project and for the analyses of the data. ESH-20 also provided office space and work related facilities for the students while they were conducting their duties. Carey Bare, Phil Fresquez, Hector Hinojosa, and Sam Loftin provided critical review and comments to earlier drafts of this report. Mary Mullen evaluated the statistical analyses and provided helpful comments.

\subsection{Literature Cited}

Allen, Craig D. 1989. Changes in the landscape of the Jemez Mountains, New Mexico. Ph.D. dissertation, University of California, Berkeley, California.

Anderson, Hal E. 1982. Aids to determining fuel models for estimating fire behavior. General Technical Report INT-122, USDA Forest Service, Intermountain Forest and Range Experiment Station, Ogden, Utah.

Andrews, Patricia L. 1986. BEHAVE: Fire behavior prediction and fuel modeling systemBURN Subsystem, part 1. General Technical Report INT-194, USDA Forest Service, Intermountain Research Station, Ogden, Utah.

Andrews, Patricia L. and Carolyn H. Chase. 1989. BEHAVE: Fire behavior prediction and fuel modeling system-BURN Subsystem, part 2. General Technical Report INT-260, USDA Forest Service, Intermountain Research Station, Ogden, Utah.

Balice, Randy G. 1996. Biological assessment for the Dome Fire Emergency Actions. LA-UR96-3615, Los Alamos National Laboratory, Los Alamos, New Mexico.

Balice, Randy G., Scott G. Ferran, Teralene S. Foxx. 1997. Preliminary Land Cover Classification for the Los Alamos Region. LA-UR-97-4627, Los Alamos National Laboratory, Los Alamos, New Mexico. 
Brown, James K., Rick D. Oberheu, Cameron M. Johnston. 1982. Handbook for inventorying surface fuels and biomass in the interior west. USDA Forest Service, General Technical Report INT-129, Intermountain Forest and Range Experiment Station, Ogden, Utah.

Foxx, Teralene S. 1984. Description of La Mesa Fire. Pages 3-6 in La Mesa Fire Symposium (compiled by Teralene S. Foxx). LA-9236-NERP, Los Alamos National Laboratory, Los Alamos, New Mexico.

Foxx, Teralene S. and Gail D. Tierney. 1980. Status of the flora of the Los Alamos National Environmental Research Park. LA-8050-NERP, Vol I., Los Alamos Scientific Laboratory, Los Alamos, New Mexico.

Foxx, Teralene S. and Gail D. Tierney. 1984. Status of the flora of the Los Alamos National Environmental Research Park, a historical perspective. LA-8050-NERP, Vol II., Los Alamos Scientific Laboratory, Los Alamos, New Mexico.

Koch, Steven W., Thomas K. Budge, and Randy G. Balice. 1997. Development of a land cover map for Los Alamos National Laboratory and vicinity. LA-UR-97-4628, Los Alamos National Laboratory, Los Alamos, New Mexico.

The New Mexican. 1954. Wind Pushes Flames Away From A-City. Article by Steve Lowell, staff writer for the Santa Fe New Mexican, June 6, 1954. Santa Fe, New Mexico. 


\section{Appendix A: Summaries of Physical Characteristics and Overstory Data for Fuels Inventory Sites Sampled in 1997}

Table A-1. Summary of physical site information and overstory data for piñon-juniper woodlands in canyons.

\begin{tabular}{|l|r|r|r|r|r|r|r|r|r|r|}
\hline Plot & Elev & Slope & Aspect & Expos & Can \% & Tree Ht & Av C Ht & T/A (>3) & T/A (3-8) & T/A (>8) \\
\hline LFI31 & 6450 & 54 & 193 & 53.9 & 13 & 12.3 & 1.7 & 41 & 37 & 4 \\
\hline LFI14 & 6460 & 10 & 30 & -9.4 & 22 & 31.4 & 4.7 & 41 & 8 & 33 \\
\hline LFI15 & 6480 & 8 & 58 & -5.4 & 15 & 22.1 & 1.1 & 39 & 15 & 25 \\
\hline LFI19 & 6510 & 8 & 9 & -8.0 & 9 & 15.6 & 0.6 & 21 & 12 & 8 \\
\hline LFI18 & 6535 & 8 & 72 & -3.8 & 15 & 20.7 & 2.1 & 112 & 58 & 54 \\
\hline LFI13 & 6540 & 8 & 345 & -7.3 & 10 & 9.5 & 0.2 & 91 & 87 & 4 \\
\hline LFI12 & 6570 & 17 & 340 & -14.7 & 49 & 18.0 & 2.3 & 99 & 58 & 41 \\
\hline LFI17 & 6580 & 6 & 30 & -5.6 & 38 & 26.4 & 3.8 & 133 & 95 & 37 \\
\hline & & & & & & & & & & \\
\hline Avg & 6515.63 & 14.88 & & -0.02 & 21.38 & 19.50 & 2.06 & 72.26 & 46.37 & 25.90 \\
\hline $\begin{array}{l}\text { Std } \\
\text { Dev }\end{array}$ & 48.95 & 16.15 & & 22.05 & 14.51 & 7.24 & 1.54 & 41.30 & 33.83 & 18.76 \\
\hline Std Err & 17.31 & 5.71 & & 7.80 & 5.13 & 2.56 & 0.55 & 14.60 & 11.96 & 6.63 \\
\hline CV \% & 0.75 & 108.60 & & -93089 & 67.89 & 37.12 & 74.89 & 57.15 & 72.97 & 72.44 \\
\hline
\end{tabular}

Table A-2. Summary of physical site information and overstory data for piñon-juniper woodlands on mesas.

\begin{tabular}{|l|r|r|r|r|r|r|r|r|r|r|}
\hline \multicolumn{1}{|c|}{ Plot } & \multicolumn{1}{|c|}{ Elev } & Slope & Aspect & Expos & Can \% & Tree Ht & Av C Ht & T/A (>3) & T/A (3-8) & T/A (>8) \\
\hline LFI16 & 6535 & 3 & 150 & 2.3 & 50 & 24.1 & 1.1 & 145 & 87 & 58 \\
\hline LFI20 & 6820 & 5 & 145 & 3.5 & 26 & 22.0 & 2.4 & 112 & 83 & 29 \\
\hline LFI24 & 6830 & 7 & 28 & -6.7 & 26 & 22.3 & 2.3 & 83 & 54 & 29 \\
\hline LFI25 & 6840 & 8 & 28 & -7.6 & 10 & 27.8 & 7.5 & 54 & 21 & 33 \\
\hline LFI45 & 6870 & 5 & 166 & 4.6 & 24 & 24.5 & & 99 & 82 & 17 \\
\hline LFI09 & 6990 & 6 & 295 & -1.6 & 13 & 12.0 & 0.3 & 79 & 62 & 17 \\
\hline LFI11 & 7070 & 2 & 130 & 1.0 & 31 & 14.0 & 2.6 & 141 & 91 & 50 \\
\hline & & & & & & & & & & \\
\hline Avg & 6850.71 & 5.14 & & -0.63 & 25.71 & 20.96 & 2.70 & 101.82 & 68.67 & 33.15 \\
\hline Std Dev & 167.84 & 2.12 & & 4.86 & 13.10 & 5.78 & 2.51 & 33.39 & 25.19 & 15.69 \\
\hline Std Err & 63.44 & 0.80 & & 1.84 & 4.95 & 2.19 & 1.03 & 13.63 & 10.28 & 6.40 \\
\hline CV \% & 2.45 & 41.14 & & -769.50 & 50.94 & 27.60 & 93.14 & 32.80 & 36.68 & 47.32 \\
\hline
\end{tabular}


Table A-3. Summary of physical site information and overstory data for ponderosa pine forests in canyons.

\begin{tabular}{|l|r|r|r|r|r|r|r|r|r|r|}
\hline \multicolumn{1}{|c|}{ Plot } & Elev & Slope & Aspect & Expos & Can \% & Tree Ht & Av C Ht & T/A (>3) & T/A (3-8) & T/A (>8) \\
\hline LFI28 & 6315 & 5 & 189 & 5.0 & 16 & 46.0 & 11.5 & 25 & 0 & 25 \\
\hline LFI34 & 6690 & 42 & 338 & -35.6 & 37 & 64.6 & 15.2 & 41 & 0 & 41 \\
\hline LFI35 & 6740 & 11 & 40 & -9.5 & 45 & 47.0 & 11.0 & 79 & 37 & 41 \\
\hline LFI39 & 7000 & 48 & 184 & 47.7 & 20 & 77.0 & & 62 & 21 & 41 \\
\hline LFI40 & 7010 & 25 & 192 & 25.0 & 71 & 68.5 & & 174 & 112 & 62 \\
\hline & & & & & & & & & & \\
\hline Avg & 6751.00 & 26.20 & & 6.52 & 37.80 & 60.62 & 12.57 & 76.24 & 33.98 & 42.27 \\
\hline Std Dev & 284.17 & 18.75 & & 31.92 & 22.06 & 13.65 & 2.29 & 58.35 & 46.27 & 13.23 \\
\hline Std Err & 127.09 & 8.39 & & 14.27 & 9.87 & 6.11 & 1.32 & 33.69 & 26.71 & 7.64 \\
\hline CV \% & 4.21 & 71.58 & & 489.90 & 58.36 & 22.52 & 18.26 & 76.53 & 136.18 & 31.31 \\
\hline
\end{tabular}

Table A-4. Summary of physical site information and overstory data for ponderosa pine forests on mesas.

\begin{tabular}{|l|r|r|r|r|r|r|r|r|r|r|}
\hline Plot & Elev & Slope & Aspect & Expos & Can \% & Tree Ht & Av C Ht & T/A (>3) & T/A (3-8) & T/A (>8) \\
\hline LFI21 & 6815 & 14 & 48 & -11.0 & 44 & 41.8 & 9.9 & 87 & 17 & 70 \\
\hline LFI10 & 7020 & 11 & 340 & -9.5 & 24 & 65.9 & 14.3 & 41 & 8 & 33 \\
\hline LFI01 & 7495 & 8 & 135 & 4.6 & 68 & 67.2 & 18.7 & 290 & 128 & 162 \\
\hline LFI36 & 7530 & 4 & 352 & -3.8 & 84 & 48.2 & 17.6 & 137 & 70 & 66 \\
\hline LFI44 & 7550 & 3 & 10 & -3.0 & 71 & 34.5 & & 186 & 58 & 128 \\
\hline LFI22 & 7570 & 17 & 10 & -17.0 & 68 & 53.6 & 18.5 & 128 & 12 & 116 \\
\hline LFI37 & 7570 & 3 & 23 & -2.9 & 74 & 55.3 & 22.2 & 124 & 21 & 104 \\
\hline LFI23 & 7610 & 3 & 330 & -2.3 & 84 & 50.0 & 23.3 & 112 & 33 & 79 \\
\hline LFI03 & 7660 & 8 & 95 & -0.7 & 27 & 75.4 & 20.7 & 66 & 0 & 66 \\
\hline LFI06 & 7680 & 10 & 104 & 0.7 & 60 & 49.9 & 10.7 & 95 & 25 & 70 \\
\hline LFI07 & 7680 & 11 & 142 & 7.4 & 74 & 55.7 & 10.6 & 75 & 17 & 58 \\
\hline LFI02 & 7685 & 12 & 126 & 5.3 & 72 & 76.7 & 25.1 & 66 & 0 & 66 \\
\hline LFI30 & 7700 & 16 & 90 & -2.8 & 76 & 60.1 & 12.5 & 311 & 244 & 66 \\
\hline LFI32 & 7710 & 10 & 149 & 7.5 & 72 & 61.3 & 27.1 & 112 & 17 & 95 \\
\hline LFI33 & 7720 & 7 & 106 & 0.7 & 79 & 53.0 & & 261 & 75 & 186 \\
\hline FFI01 & 7735 & 26 & 110 & 4.5 & 25 & 75.1 & 25.1 & 172 & 69 & 104 \\
\hline LFI05 & 7740 & 10 & 116 & 2.8 & 83 & 47.8 & 21.7 & 133 & 8 & 124 \\
\hline LFI29 & 7740 & 32 & 75 & -13.5 & 85 & 61.2 & 13.3 & 348 & 257 & 91 \\
\hline LFI08 & 7760 & 9 & 90 & -1.6 & 85 & 73.5 & 26.6 & 91 & 0 & 91 \\
\hline LFI26 & 7760 & 13 & 100 & 0.0 & 52 & 50.3 & 15.9 & 128 & 37 & 91 \\
\hline LFI27 & 7780 & 8 & 15 & -8.0 & 73 & 41.7 & 16.7 & 133 & 41 & 91 \\
\hline LFI04 & 7810 & 11 & 92 & -1.5 & 22 & 67.1 & 19.9 & 37 & 0 & 37 \\
\hline FFI02 & 7840 & 10 & 115 & 2.6 & 36 & 63.0 & 24.4 & 164 & 69 & 95 \\
\hline & & & & & & & & & & \\
\hline Avg & 7615.65 & 11.13 & & -1.81 & 62.52 & 57.75 & 18.80 & 143.43 & 52.45 & 90.98 \\
\hline Std Dev & 240.28 & 6.85 & & 6.46 & 21.79 & 11.66 & 5.49 & 84.73 & 70.29 & 35.90 \\
\hline Std Err & 50.10 & 1.43 & & 1.35 & 4.54 & 2.43 & 1.20 & 17.67 & 14.66 & 7.48 \\
\hline CV \% & 3.16 & 61.55 & & -357.23 & 34.86 & 20.19 & 29.19 & 59.07 & 134.00 & 39.45 \\
\hline
\end{tabular}


Table A-5. Summary of physical site information and overstory data for mixed conifer forests in canyons.

\begin{tabular}{|c|c|c|c|c|c|c|c|c|c|c|}
\hline Plot & Elev & Slope & Aspect & Expos & Can \% & Tree Ht & Av C Ht & $\mathrm{T} / \mathrm{A}(>\mathbf{3})$ & T/A (3-8) & T/A (>8) \\
\hline LFI38 & 6990 & 72 & 4 & -71.6 & 69 & 66.5 & & 340 & 253 & 87 \\
\hline \begin{tabular}{|l|} 
LFI41 \\
\end{tabular} & 7010 & 40 & 22 & -39.1 & 85 & 41.0 & & 240 & 178 & 62 \\
\hline LFI42 & 7020 & 30 & 2 & -29.7 & 64 & & & 278 & 211 & 66 \\
\hline LFI43 & 7320 & 40 & 12 & -40.0 & 83 & 52.5 & & 506 & 423 & 83 \\
\hline FFI04 & 7730 & 52 & 22 & -50.9 & 78 & 40.0 & & 157 & 95 & 62 \\
\hline FFI03 & 7780 & 60 & 164 & 53.9 & 59 & 73.0 & & 319 & 207 & 112 \\
\hline & וon 0 & 1000 & & 5al & 7200 & 5160 & & 30662 & 207001 & ו \\
\hline \begin{tabular}{|l} 
Avg \\
Std Dev
\end{tabular} & $\frac{1308.33}{367.12}$ & $\frac{49.00}{15.38}$ & & $\frac{-29.56}{43.34}$ & $\frac{73.00}{10.60}$ & $\frac{54.00}{14.86}$ & & $\frac{306.63}{116.88}$ & $\frac{227.90}{108.91}$ & $\frac{78.73}{19.44}$ \\
\hline Std Err & 149.88 & 6.28 & & 17.69 & 4.33 & 6.64 & & 47.71 & 44.46 & 7.93 \\
\hline CV \% & 5.02 & 31.38 & & -146.63 & 14.52 & 27.21 & & 38.12 & 47.79 & 24.69 \\
\hline
\end{tabular}

Table A-6. Summary of physical site information and overstory data for mixed conifer forests in mountains.

\begin{tabular}{|c|c|c|c|c|c|c|c|c|c|c|}
\hline Plot & Elev & Slope & Aspect & Expos & Can \% & Tree Ht & Av C Ht & $\mathrm{T} / \mathrm{A}(>3)$ & T/A (3-8) & T/A (>8) \\
\hline FFI05 & 8085 & 35 & 2 & -34.7 & 75 & 78.5 & & 298 & 220 & 79 \\
\hline FFI07 & 8120 & 25 & 9 & -25.0 & 81 & & & 381 & 257 & 124 \\
\hline FFI06 & 8220 & 15 & 146 & 10.8 & 57 & & & 265 & 124 & 141 \\
\hline FFI08 & 8480 & 28 & 193 & 28.0 & 60 & 60.0 & & 294 & 174 & 120 \\
\hline FFI09 & 9060 & 20 & $\overline{11}$ & -20.0 & 83 & 60.0 & & 481 & 336 & 145 \\
\hline & & & & & & & & & & \\
\hline Avg & 8393.00 & 24.60 & & -8.18 & 71.20 & 66.17 & & 343.92 & 222.10 & 121.82 \\
\hline Std Dev & 403.66 & 7.64 & & 26.41 & 12.01 & 10.68 & & 87.80 & 80.59 & 26.30 \\
\hline Std Err & 180.52 & 3.41 & & 11.81 & 5.37 & 6.17 & & 39.27 & 36.04 & 11.76 \\
\hline CV \% & 4.81 & 31.04 & & -322.84 & 16.87 & 16.14 & & 25.53 & 36.29 & 21.59 \\
\hline
\end{tabular}




\section{Appendix B: Summaries of Understory Fuel Levels for Fuels Inventory Sites Sampled in 1997}

Table B-1. Summary of understory fuel levels for piñon-juniper woodlands in canyons.

\begin{tabular}{|c|c|c|c|c|c|c|c|c|c|}
\hline Plot & $1 \mathrm{hr}$ & $10 \mathrm{hr}$ & $100 \mathrm{hr}$ & $1000 \mathrm{hrS}$ & $1000 \mathrm{hr} R$ & Duff & Litter & Veg & Total \\
\hline FI31 & 0.270 & 0.234 & 0.000 & 0.000 & 0.000 & 1.139 & 0.000 & 0.000 & 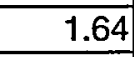 \\
\hline LFl14 & 204 & 1.509 & 456 & 728 & 2.038 & .058 & 585 & 0.015 & \\
\hline LFI15 & 0.219 & 0.744 & 1.184 & 0.407 & 15.557 & 3.002 & .778 & 0.027 & 21 \\
\hline LFI19 & 0.305 & 0.665 & 0.363 & .071 & 0.000 & 2.001 & 55 & .006 & \\
\hline LFl18 & 0.266 & 1.124 & 182 & 1.528 & 639 & 2.918 & .596 & 0.062 & \\
\hline LFI13 & 0.218 & 1.642 & 911 & 053 & 1.165 & .114 & .000 & 0.068 & 10. \\
\hline LFI12 & 0.296 & 2.372 & 460 & 389 & 379 & 5.614 & 2.682 & 0.049 & 15. \\
\hline FI17 & 0.320 & 1.524 & 1.000 & 0.669 & 0.093 & 2.362 & 1.300 & 0.018 & \\
\hline & & & & & & & & & \\
\hline & 0.262 & 1.227 & 694 & 481 & 2.859 & 3.401 & 1824 & 0.031 & 9.77 \\
\hline $\mathrm{dD}$ & 0.044 & 676 & 434 & 506 & 264 & 1.742 & .860 & 0.026 & 6.3 \\
\hline $\mathrm{dErr}$ & 0.016 & 0.239 & .154 & 0.179 & 1.861 & 0.616 & 0.304 & 0.009 & 2.2 \\
\hline $1 \%$ & 16.855 & 55.089 & 62.550 & 105.206 & 184.144 & 51.213 & 104.304 & 84.455 & 65.1 \\
\hline
\end{tabular}

Table B-2. Summary of understory fuel levels for piñon-juniper woodlands on mesas.

\begin{tabular}{|l|r|r|r|r|r|r|r|r|r|}
\hline \multicolumn{1}{|c|}{ Plot } & \multicolumn{1}{c|}{$\mathbf{1 ~ h r}$} & \multicolumn{1}{|c|}{$\mathbf{1 0} \mathbf{~ h r}$} & $\mathbf{1 0 0} \mathbf{~ h r}$ & $\mathbf{1 0 0 0} \mathbf{~ h r ~ S}$ & $\mathbf{1 0 0 0} \mathbf{~ h r ~ R}$ & \multicolumn{1}{c|}{ Duff } & \multicolumn{1}{c|}{ Litter } & \multicolumn{1}{c|}{ Veg } & \multicolumn{1}{c|}{ Total } \\
\hline LFl16 & 0.454 & 1.997 & 0.999 & 0.984 & 0.564 & 4.502 & 1.794 & 0.005 & 11.30 \\
\hline LFI20 & 0.269 & 2.246 & 1.545 & 0.798 & 8.854 & 4.030 & 2.289 & 0.000 & 20.03 \\
\hline LFI24 & 0.283 & 1.887 & 1.092 & 1.041 & 0.843 & 2.751 & 0.424 & 0.032 & 8.35 \\
\hline LFI25 & 0.192 & 1.354 & 0.091 & 0.000 & 8.380 & 4.085 & 3.834 & 0.068 & 18.01 \\
\hline LFI45 & 0.547 & 1.142 & 1.090 & 0.199 & 1.602 & 4.030 & 1.780 & 0.013 & 10.40 \\
\hline LFI09 & 0.324 & 1.638 & 1.000 & 5.781 & 0.000 & 2.724 & 0.000 & 0.037 & 11.50 \\
\hline LFI11 & 0.231 & 1.122 & 0.454 & 2.260 & 0.000 & 3.335 & 1.711 & 0.058 & 9.17 \\
\hline & & & & & & & & & \\
\hline Avg & 0.329 & 1.626 & 0.896 & 1.580 & 2.892 & 3.637 & 1.690 & 0.030 & 12.681 \\
\hline Std DeV & 0.127 & 0.438 & 0.476 & 1.990 & 3.951 & 0.703 & 1.254 & 0.026 & 4.508 \\
\hline Std Err & 0.048 & 0.166 & 0.180 & 0.752 & 1.493 & 0.266 & 0.474 & 0.010 & 1.704 \\
\hline CV \% & 38.705 & 26.949 & 53.185 & 125.960 & 136.630 & 19.340 & 74.182 & 86.434 & 35.548 \\
\hline
\end{tabular}

Table B-3. Summary of understory fuel levels for ponderosa pine forests in canyons.

\begin{tabular}{|c|c|c|c|c|c|c|c|c|c|}
\hline Plot & $1 \mathrm{hr}$ & $10 \mathrm{hr}$ & $100 \mathrm{hr}$ & $1000 \mathrm{hr} \mathrm{S}$ & 1000 hr R & Duff & Litter & Veg & Total \\
\hline LFI28 & 0.264 & 1.598 & 0.363 & 0.789 & 0.529 & 6.198 & 0.000 & 0.000 & 9.74 \\
\hline LFI34 & 0.211 & 2.536 & 0.591 & 0.792 & 2.110 & 18.593 & 0.000 & 0.000 & 24.83 \\
\hline LFI35 & 0.235 & 1.817 & 0.183 & 0.000 & 12.356 & 10.339 & 0.000 & 0.000 & 24.93 \\
\hline LFI39 & 0.303 & 1.054 & 0.503 & 0.000 & 0.248 & 4.891 & 0.613 & 0.031 & 7.64 \\
\hline LFI40 & 0.230 & 2.351 & 1.777 & 0.246 & 6.945 & 8.338 & 2.496 & 0.002 & 22.39 \\
\hline Avg & 0.249 & 1.871 & 0.683 & 0.365 & 4.438 & 9.672 & 0.622 & 0.007 & 17.907 \\
\hline Std Dev & 0.036 & 0.595 & 0.631 & 0.401 & 5.178 & 5.402 & 1.081 & 0.014 & 8.505 \\
\hline Std Err & 0.016 & 0.266 & 0.282 & 0.179 & 2.316 & 2.416 & 0.483 & 0.006 & 3.804 \\
\hline CV \% & 14.447 & 31.816 & 92.287 & 109.726 & 116.677 & 55.856 & 173.842 & 205.117 & 47.497 \\
\hline
\end{tabular}


Table B-4. Summary of understory fuel levels for ponderosa pine forests on mesas.

\begin{tabular}{|c|c|c|c|c|c|c|c|c|c|}
\hline Plot & $1 \mathrm{hr}$ & $10 \mathrm{hr}$ & $100 \mathrm{hr}$ & $1000 \mathrm{hr} \mathrm{S}$ & $1000 \mathrm{hr} \mathrm{R}$ & Duff & Litter & Veg & Total \\
\hline LFI21 & 0.189 & 2.515 & 0.550 & 0.000 & 5.699 & 7.004 & 4.610 & 0.001 & 20.57 \\
\hline LFI10 & 0.195 & 2.314 & 1.096 & 0.085 & 22.164 & 9.338 & 0.211 & 0.060 & 35.46 \\
\hline LFI01 & 0.017 & 1.144 & 0.728 & 0.280 & 1.048 & 7.115 & 0.648 & 0.023 & 11.00 \\
\hline LFI36 & 0.263 & 2.378 & 0.636 & 0.170 & 1.825 & 10.478 & 0.000 & 0.000 & 15.75 \\
\hline LFI44 & 0.241 & 1.465 & 0.182 & 0.000 & 3.055 & 8.060 & 1.690 & 0.006 & 14.70 \\
\hline LFI22 & 0.224 & 4.107 & 1.105 & 3.209 & 8.355 & 11.145 & 0.196 & 0.029 & 28.37 \\
\hline LFI37 & 0.228 & 1.902 & 1.089 & 1.061 & 3.240 & 7.448 & 0.000 & 0.000 & 14.97 \\
\hline LFI23 & 0.221 & 2.301 & 0.636 & 1.725 & 2.900 & 8.810 & 1.112 & 0.036 & 17.74 \\
\hline LFI03 & 0.067 & 0.362 & 0.910 & 1.313 & 2.765 & 4.308 & 0.181 & 0.000 & 9.91 \\
\hline LFI06 & 0.064 & 4.247 & 1.455 & 1.277 & 6.173 & 11.172 & 0.847 & 0.000 & 25.24 \\
\hline LFI07 & 0.162 & 2.658 & 0.913 & 0.974 & 1.406 & 11.478 & 1.232 & 0.034 & 18.86 \\
\hline LFI02 & 0.078 & 2.726 & 2.932 & 3.085 & 8.556 & 4.419 & 0.902 & 0.008 & 22.71 \\
\hline LFI30 & 0.273 & 3.080 & 0.919 & 2.131 & 4.371 & 13.674 & 0.000 & 0.000 & 24.45 \\
\hline LFI32 & 0.284 & 1.834 & 0.365 & 0.000 & 9.286 & 8.504 & 1.054 & 0.007 & 21.33 \\
\hline LFI33 & 0.227 & 2.516 & 1.001 & 0.362 & 12.547 & 10.672 & 1.230 & 0.017 & 28.57 \\
\hline FFI01 & 0.161 & 1.552 & 1.313 & 1.849 & 0.670 & 6.059 & 0.700 & 0.010 & 12.31 \\
\hline LFI05 & 0.029 & 1.600 & 0.455 & 1.573 & 2.921 & 8.894 & 0.950 & 0.004 & 16.43 \\
\hline LFI29 & 0.239 & 2.934 & 1.239 & 1.778 & 3.662 & 12.423 & 0.000 & 0.000 & 22.27 \\
\hline LFI08 & 0.175 & 1.735 & 0.455 & 0.855 & 1.207 & 6.198 & 1.409 & 0.000 & 12.03 \\
\hline LFI26 & 0.203 & 2.109 & 0.824 & 0.372 & 37.856 & 6.364 & 1.332 & 0.007 & 49.07 \\
\hline LFI27 & 0.192 & 2.670 & 0.637 & 1.569 & 9.608 & 8.449 & 1.405 & 0.000 & 24.53 \\
\hline LFI04 & 0.045 & 2.689 & 0.637 & 1.845 & 2.065 & 7.004 & 0.445 & 0.002 & 14.73 \\
\hline FFI02 & 0.192 & 2.829 & 0.821 & 4.231 & 1.633 & 5.920 & 0.489 & 0.003 & 16.12 \\
\hline Avg & 0.173 & 2333 & 0.909 & 1293 & 6.653 & 8.475 & 0.898 & 0.011 & 20.744 \\
\hline Std Dev & 0.082 & 0.868 & 0.543 & 1.133 & 8.389 & 2.515 & 0.967 & 0.016 & 8.883 \\
\hline Std Err & 0.017 & 0.181 & 0.113 & 0.236 & 1.749 & 0.524 & 0.202 & 0.003 & 1.852 \\
\hline $\mathrm{CV} \%$ & 47.32 & 37.21 & 59.78 & 87.60 & 126.09 & 29.67 & 107.79 & 145.97 & 42.82 \\
\hline
\end{tabular}

Table B-5. Summary of understory fuel levels for mixed conifer forests in canyons.

\begin{tabular}{|l|r|r|r|r|r|r|r|r|r|}
\hline \multicolumn{1}{|c|}{ Plot } & \multicolumn{1}{c|}{$\mathbf{~ h r}$} & \multicolumn{1}{|c|}{$\mathbf{1 0} \mathbf{~ h r}$} & \multicolumn{1}{|c|}{$\mathbf{1 0 0} \mathbf{~ h r}$} & $\mathbf{1 0 0 0} \mathbf{~ h r} \mathbf{~}$ & $\mathbf{1 0 0 0} \mathbf{~ h r} \mathbf{R}$ & \multicolumn{1}{c|}{ Duff } & \multicolumn{1}{c|}{ Litter } & \multicolumn{1}{c|}{ Veg } & \multicolumn{1}{c|}{ Total } \\
\hline LFI38 & 1.013 & 2.926 & 1.430 & 1.336 & 12.473 & 13.674 & 1.570 & 0.003 & 34.43 \\
\hline LFI41 & 1.226 & 1.720 & 0.880 & 1.359 & 0.336 & 14.341 & 0.715 & 0.001 & 20.58 \\
\hline LFI42 & 0.680 & 2.063 & 1.909 & 1.501 & 5.000 & 12.951 & 1.532 & 0.022 & 25.66 \\
\hline LFI43 & 0.321 & 6.716 & 0.586 & 0.000 & 12.247 & 10.672 & 1.679 & 0.000 & 32.22 \\
\hline FFI04 & 1.435 & 3.300 & 8.183 & 2.966 & 14.393 & 13.285 & 1.995 & 0.009 & 45.56 \\
\hline FFI03 & 0.944 & 1.862 & 2.117 & 0.170 & 40.980 & 9.922 & 0.936 & 0.007 & 56.94 \\
\hline & & & & & & & & & \\
\hline Avg & 0.937 & 3.098 & 2.517 & 1.222 & 14.238 & 12.474 & 1.405 & 0.007 & 35.898 \\
\hline Std Dev & 0.396 & 1.879 & 2.836 & 1.072 & 14.148 & 1.765 & 0.482 & 0.008 & 13.352 \\
\hline Std Err & 0.162 & 0.767 & 1.158 & 0.438 & 5.776 & 0.720 & 0.197 & 0.003 & 5.451 \\
\hline CV \% & 42.249 & 60.663 & 112.665 & 87.767 & 99.365 & 14.146 & 34.336 & 114.377 & 37.194 \\
\hline
\end{tabular}


Table B-6. Summary of understory fuel levels for mixed conifer forests in mountains.

\begin{tabular}{|l|r|r|r|r|r|r|r|r|r|}
\hline \multicolumn{1}{|c|}{ Plot } & \multicolumn{1}{c|}{$\mathbf{~ h r}$} & \multicolumn{1}{c|}{$\mathbf{1 0} \mathbf{~ h r}$} & $\mathbf{1 0 0} \mathbf{~ h r}$ & $\mathbf{1 0 0 0} \mathbf{~ h r ~ S}$ & $\mathbf{1 0 0 0} \mathbf{~ h r ~ R}$ & \multicolumn{1}{c|}{ Duff } & \multicolumn{1}{c|}{ Litter } & \multicolumn{1}{c|}{ Veg } & \multicolumn{1}{c|}{ Total } \\
\hline FFI05 & 0.605 & 2.216 & 3.077 & 4.347 & 45.157 & 11.395 & 1.040 & 0.000 & 67.84 \\
\hline FFI07 & 1.034 & 1.999 & 4.303 & 2.270 & 26.542 & 9.116 & 1.040 & 0.014 & 46.32 \\
\hline FFI06 & 0.444 & 1.730 & 2.569 & 1.220 & 17.513 & 5.697 & 0.000 & 0.000 & 29.17 \\
\hline FFI08 & 0.354 & 2.132 & 2.544 & 0.000 & 22.229 & 9.755 & 1.480 & 0.004 & 38.50 \\
\hline FFl09 & 0.614 & 1.861 & 4.442 & 8.355 & 31.628 & 9.672 & 0.000 & 0.000 & 56.57 \\
\hline & & & & & & & & & \\
\hline Avg & 0.610 & 1.988 & 3.387 & 3.239 & 28.614 & 9.127 & 0.712 & 0.004 & 47.680 \\
\hline Std Dev & 0.261 & 0.197 & 0.926 & 3.275 & 10.619 & 2.097 & 0.674 & 0.006 & 15.116 \\
\hline Std Err & 0.117 & 0.088 & 0.414 & 1.465 & 4.749 & 0.938 & 0.302 & 0.003 & 6.760 \\
\hline CV \% & 42.80 & 9.91 & 27.33 & 101.13 & 37.11 & 22.98 & 94.70 & 165.15 & 31.70 \\
\hline
\end{tabular}

